the labour ward, getting started in breast feeding, and willingness to deliver another child later.

Mothers' were also asked:

Did you have confidence in yourself during your delivery/ confidence in the staff? Did you experience tolerable pain intolerable pain/fear that your delivery would not succeed/ fear that your baby would not survive/fear that you would not survive?

Did you feel exhausted?

Did you feel that your delivery was easier/more difficult than you had expected?

Was your childbirth a period of happiness/horror?

Was the atmosphere at the hospital reception friendly/ encouraging/calm/busy/harsh/nervous/fear inducing and stress inducing/fear reducing and stress reducing?

How did you experience your labour pains?

How would you assess the atmosphere at the puerperal department?

How well did getting breast feeding started succeed?

Are you still breast feeding? (At the time of the three month follow up)

Would you like to have another baby?

PARENTS' SOCIODEMOGRAPHIC VARIABLES

Age

Basic education

Vocational education

Occupation

Estimation about one's own social position.

1 Miller AR, Barr RG. Infantile colic, is it a gut issue? Pediatr Clin North Am 1991;38:1407-23.

2 Wessel MA, Cobb JC, Jackson EB, Jackson EB, Harris GS, Detwiler AC Paroxysmal fussing in infancy, sometimes called "colic." Pediatrics 1954;14: 421-34.

3 White PJ. The relation between colic and eczema in early infancy. $A m \mathcal{f} D i$ Child 1929;38:935-42.

4 Rubin SP, Prendergast M. Infantile colic: incidence and treatment in Norfolk community. Child Care Health Dev 1984;10:219-26.
5 Stăhlberg MR, Infantile colic: occurrence and risk factors. Eur $f$ Pediatr 1984;143:108-11.

6 Hide DW, Guyer BM. Prevalence of infant colic. Arch Dis Child 1982:57:55960.

7 Forsyth BWC. Colic and the effect of changing formulas: a double-blind, multiple-crossover study. F Pediatr 1989;115:521-6.

8 Miller JJ, McVeagh P, Fleet GH, Petocz P, Brand JC. Breath hydrogen excretion in infants with colic. Arch Dis Child 1989;64:725-9.

9 Moore DJ, Robb TA, Davidson GP. Breath hydrogen response to milk containing lactose in colicky and non-colicky infants. $\mathcal{f}$ Pediatr 1988;113 979-84.

10 Neff FC. The treatment of colic in infants. $\Im A M A 1940 ; 114: 1745-8$.

11 Carey WB. Clinical applications of infants temperament measurements. f Pediatr 1972;81:823-8.

12 Spock B. Etiological factors in hypertrophic pyloric stenosis and infantile colic. Psychosom Med 1944;6:162-5.

13 Carey WB. Maternal anxiety and infantile colic. Clin Pediatr (Phila) 1968;7: 590-5.

14 Paradise JL. Maternal and other factors in the etiology of infantile colic. IAMA 1966;197:191-9.

15 Hewson P, Oberklaid F, Menahem S. Infant colic, distress and crying. Clin Pediatr (Phila) 1987;26:69-76.

16 Central Statistical Office. Statistical yearbook of Finland. Vol 82. Helsinki Central Statistical Office of Finland, 1987.

17 Rautava P, Sillanpää $M$. The Finnish family competence study: knowledge of childbirth of nulliparae seen at maternity health care clinics. 7 Epidemio Community Health 1989;43:253-60.

18 Rautava P. The Finnish family competence study: characteristics of pregnan women with low childbirth knowledge. Soc Sci Med 1989;29:1105-9.

19 Agresti A. Categorical data analysis. New York: John Wiley and Sons, 1990

20 Dixon WJ, Brown MB, Engelman L, Jennrich RI. BMDP statistical software manual. Vol 1 and 2. Berkley CA: University of California Press, 1990.

21 Illingworth RS. "Three months' colic." Arch Dis Child 1954;29:165-74.

22 Hill DJ, Menahem S, Hudson I, Sheffield L, Shelton M, Oberklaid F, et al. Charting infant distress: an aid to defining colic. F Pediatr 1992;121:755-8.

23 Lester BM, Boukydis CFZ, Carcia-Coll CT, Hole WT. Colic for developmentalists. Infant Mental Health F 1990;11:321-33.

24 Thomas DW, McGilligan K, Eisenberg LD, Liederman HM, Rissman EM Infantile colic and type of milk feeding. Am $\mathcal{F}$ Dis Child 1987;141:451-3.

25 Matheson I, Rivrud GN. The effect of smoking on lactation and infantile colic. JAMA 1989;261:42-3.

26 Illingworth RS. Infant colic revisited. Arch Dis Child 1985;60:981-5.

27 Thompson PE, Harris CC, Bitowski BE. Effects of infant colic on the family: implications for practice. Comprehensive Pediatric Nursing 1986;9:273-85.

28 Winnicot DW. The maturational processes and the facilitating environment Boston: International Universities Press, 1991.

(Accepted 18 fune 1993)

\title{
Changes in ethnic minority membership of health authorities 1989-92
}

\author{
Nick Jewson, David Mason, Helen Bourke, \\ Chris Bracebridge, Frances Brosnan, \\ Kim Milton
}

Ethnicity Research Centre, University of Leicester, Leicester LE1 7RH

Nick Jewson, codirector

David Mason, codirector

Helen Bourke, postgraduate trainee

Chris Bracebridge,

postgraduate trainee

Frances Brosnan,

postgraduate trainee

Kim Milton, postgraduate

trainee

Correspondence to:

Messrs Jewson and Mason.

BMF 1993;307:604-5
In 1989 a King's Fund survey concluded that ethnic minority membership of health authorities was already low $^{1}$ and suggested that changes proposed in Working for Patients ${ }^{2}$ could lead to a further decline. In 1992 we did a similar study of the ethnic composition of health authorities to compare the findings with the earlier data.

\section{Methods and results}

The 1992 survey used the same questionnaire as the earlier study, save only for necessary changes to categories of membership. In 1989 there were 14 regional health authorities and 190 district health authorities in England. Each comprised a chairperson and 16 or more members. The members were divided among professional (4-6), local authority (4), and generalist or lay (8) members. In 1992 there were 14 regional health authorities and 179 district health authorities (although several mergers were in progress). Their reduced membership comprised a chairperson, five non-executive members, and up to five executive members. All regional health authorities and 157 district health authorities replied to questionnaires mailed in March 1992.

In 1989 none of the chairs of regional health authorities and only seven of the 208 other members (3\%) were from ethnic minorities. In 1992 there were still no ethnic minority chairs and just two of the 141 members were of ethnic minority origin (1.4\%), both holding non-executive appointments (see table). In 1989 none of the chairs of district health authorities and $3 \%$ of the other members (89 of 2974) were from ethnic minority groups. Of these $50(56 \%)$ were Asian while a further $24(27 \%)$ were of Caribbean origin. In 1992 one district health authority reported an Asian chair. Thirty seven $(2 \cdot 6 \%)$ of the 1405 other members were from ethnic minority groups. Between 1989 and 1992 the proportion of Asian members marginally increased (from $1.6 \%$ to $1.7 \%$ ) but those of Caribbean origin declined from $0.8 \%$ to $0.1 \%$ (see table). Members from ethnic minorities were twice as likely to be non-executives than executives. The National Health Service and Community Care Act 1990 reduced total numbers of health authority members by nearly half. Between 1989 and 1992 Asian membership also roughly halved (from 50 to 26) but Afro-Caribbean membership fell disproportionately (from 24 to just 2 ).

\section{Comment}

Estimates derived from the 1991 census suggest that

Ethnic origin of members of regional and district health authorities (including chairs) in 1989 and 1992

\begin{tabular}{lrrrrr}
\hline & \multicolumn{2}{c}{ Regional authorities } & & \multicolumn{2}{c}{ District authorities } \\
\cline { 2 - 3 } \cline { 5 - 6 } & 1989 & 1992 & & 1989 & 1992 \\
\hline White & $214(97)$ & $139(99)$ & & $3066(97)$ & $1525(98)$ \\
African & $1(0 \cdot 5)$ & $1(0 \cdot 7)$ & $6(0 \cdot 2)$ & $2(0 \cdot 1)$ \\
Caribbean & $2(0 \cdot 9)$ & 0 & & $24(0 \cdot 8)$ & $2(0 \cdot 1)$ \\
Asian & $3(1 \cdot 4)$ & $1(0 \cdot 7)$ & & $50(1 \cdot 6)$ & $26(1 \cdot 7)$ \\
Other & $1(0 \cdot 5)$ & 0 & & $9(0 \cdot 3)$ & $7(0 \cdot 4)$ \\
Total & 221 & 141 & 3155 & 1562 \\
\hline
\end{tabular}


people from ethnic minorities comprise some $6 \cdot 2 \%$ of the population of England. Both the 1989 and 1992 surveys show an ethnic minority presence on health authorities considerably below this level. They also indicate a decline over the period in ethnic minority membership of regional health authorities and in AfroCaribbean membership of district health authorities. This may, in part, reflect the enhanced role of executive positions and the disappearance of local authority and generalist members. Indeed, reorganisation was intended to make health authorities more managerial with less emphasis on representation. Nevertheless, Department of Health guidance specifically enjoins authorities to seek "a greater proportion of women and candidates from ethnic minority groups..." ${ }_{3}$ and suggests that district authorities should play important local advocate functions in making the National Health
Service more responsive to the needs of local communities. A recent survey revealed that members themselves emphasised the importance of non-executives, in particular, "acting as the voice of the community." 4 Moreover, managerial effectiveness might well be heightened by the inclusion of a broader cross-section of the population. In short, it seems that fears expressed in the earlier report were not groundless.

1 King Edward's Hospital Fund for London, Equal Opportunities Task Force. Ethnic minority health authority membership: a survey. London: King's Fund, 1990.

2 Working for patients. London: HMSO, 1989;Cmnd 555.

3 Department of Health. Guidance on the membership, meetings and proceedings of NHS authorities. London: Department of Health, 1991.

4 Cairncross L, Ashburner L. Out of the bunker. Health Service fournal 1993;102:20-2.

(Accepted 2 fuly 1993)

practice is hampered both by the reluctance of staff to disclose their mistakes and their frequent lack of awareness that mistakes have happened unless clinical problems ensue. In addition to this, a retrospective questionnaire is obviously limited by accuracy of recall.

Despite these problems this study shows that most preregistration house officers surveyed used unsatisfactory methods for giving intravenous drugs. Although these findings suggest that current instruction is inadequate, consideration should also be given to other circumstances of the preregistration year

Summary of response to questionnaire on administration of intravenous drugs

\section{Regional Drug and Therapeutic Centre, Wolfson Unit of Clinical Pharmacology, Newcastle upon Tyne NE1 4LP $\mathrm{K}$ Teahon, senior registrar D N Bateman, reader in therapeutics}

Correspondence to: Dr Teahon

$B M F$ 1993;307:605-6
Preregistration house officers may spend up to one fifth of their time giving intravenous drugs, often to unfamiliar patients. ${ }^{1-3}$ The quality of their training for and their skill in performing this task have both been questioned. ${ }^{25}$ We attempted to evaluate, by anonymous questionnaire, the procedures used by preregistration house officers in giving intravenous drugs and the frequency and nature of any drug errors which they know have occurred. In addition we examined, by postal survey of medical schools, the extent of undergraduate instruction in the practicalities of parenteral drug administration.

\section{Methods and results}

An anonymous postal questionnaire was sent to 138 preregistration house officers working in 20 units in the Northern Regional Health Authority. These were mainly graduates of the University of Newcastle upon Tyne and were identified from the list of 226 house officer posts in Northern region held by the postgraduate dean's office. The survey was conducted during July 1992 (the last month of the preregistration year for most doctors). A reminder was sent two weeks after the questionnaire had been distributed, and at least two doctors from each hospital were contacted by telephone to ensure that they had received the questionnaire and to remind them and their colleagues to complete it, if they had not already done so. The questions asked are summarised in the table. One hundred and eleven $(80 \%)$ of the questionnaires were returned and all were suitable for analysis.

Questionnaires were then sent to the heads of clinical pharmacology at all 27 medical schools in the United Kingdom listed in the Medical Directory. Twenty three $(85 \%)$ replied; the table shows their comments.

The 19 doctors who could recall undergraduate or postgraduate instruction in giving intravenous drugs did not have a different error rate than the 92 who had not had instruction $\left(11 / 19 v 40 / 92 ; \chi^{2}=0 \cdot 80, \mathrm{p}=0.37\right)$. Doctors working in units where nurses routinely gave intravenous drugs (19) had a similar error recall rate to those in other units $\left(11 / 19 v 40 / 92 ; \chi^{2}=0.80, p=0 \cdot 37\right)$.

\section{Comment}

Any attempt to assess the real error rate in medical

\begin{tabular}{|c|c|}
\hline Questions & $\begin{array}{l}\text { No }(\%) \text { of } \\
\text { replies }\end{array}$ \\
\hline \multicolumn{2}{|l|}{ House officers $(n=111)$} \\
\hline Aware of hospital or district guidelines & $12(11)$ \\
\hline Can recall undergraduate instruction & $8(7)$ \\
\hline Can recall postgraduate instruction & $11(10)$ \\
\hline \multicolumn{2}{|l|}{ The staff routinely responsible for giving intravenous drugs } \\
\hline Nurses & $19(17)$ \\
\hline Doctors & $36(32)$ \\
\hline Variable & $56(51)$ \\
\hline \multicolumn{2}{|l|}{ Check patients identity wristlet against prescription sheet: } \\
\hline Never & $24(22)$ \\
\hline Rarely & $58(52)$ \\
\hline Usually & $28(25)$ \\
\hline \multirow{2}{*}{\multicolumn{2}{|c|}{ Have read data sheets of commonly administered drugs: }} \\
\hline & \\
\hline None & $7(6)$ \\
\hline Some & $56(50)$ \\
\hline Most & $43(39)$ \\
\hline All & $5(5)$ \\
\hline \multicolumn{2}{|l|}{$\begin{array}{l}\text { Double check drugs and diluents with another member of } \\
\text { staff: }\end{array}$} \\
\hline Never & $33(30)$ \\
\hline Rarely & $62(56)$ \\
\hline Usually & $14(12)$ \\
\hline Always & $2(2)$ \\
\hline \multicolumn{2}{|l|}{$\begin{array}{l}\text { Number of errors made when administering intravenous } \\
\text { drugs since February 1992: }\end{array}$} \\
\hline None & $60(54)$ \\
\hline 1 & $32(29)$ \\
\hline 2 or 3 & $17(15)$ \\
\hline 4 or 5 & $2(2)$ \\
\hline \multicolumn{2}{|l|}{ Type of errors recalled: } \\
\hline Wrong drug & $8(10)$ \\
\hline Wrong diluent & $9(11)$ \\
\hline Wrong dose of drug & $22(27)$ \\
\hline Wrong dose of diluent & $8(10)$ \\
\hline Wrong patient & $21(25)$ \\
\hline Other & $14(17)$ \\
\hline Usually flush cannula before administration & $6(5)$ \\
\hline Usually flush cannula after administration & $9(8)$ \\
\hline \multicolumn{2}{|l|}{ Medical schools $(\mathrm{n}=23)$} \\
\hline $\begin{array}{l}\text { Students are expected to learn this procedure during their } \\
\text { clinical attachments }\end{array}$ & $11(48)$ \\
\hline $\begin{array}{l}\text { Students are given a self completed "check list" of procedures } \\
\text { of which this is one }\end{array}$ & $5(22)$ \\
\hline $\begin{array}{l}\text { "Check list" of procedures is signed by whoever has done the } \\
\text { instruction }\end{array}$ & $1(4)$ \\
\hline Formal lecture session & $5(22)^{\star}$ \\
\hline Obligatory "practical skills" session & $2(8)$ \\
\hline
\end{tabular}

*Three combined lectures with check lists or practical skills sessions. Two other medical schools replied: one gave no teaching to undergraduates on this topic ("We believe this and other practical procedures should be taugh to PRHOs"; in the other "All techniques except check lists are used and individual examination is to be introduced in the near future." 